\title{
A very difficult farewell editorial
}

José Antonio Poli de Figueiredo

Editor

Cince 1986, Revista Odonto Ciência has served Dentistry as a space for case $\checkmark$ presentations, literature reviews, and, most specially, original scientific research, through manuscripts from different places of the globe. This task has been done through non-profitable work of editors, editorial boards, and reviewers, together with the scientific community, that recognized the serious work proportioned by the Dental School of the Pontifical Catholic University of Rio Grande do Sul - PUCRS. Numerous studies have been read and cited and the open access, totally free of charge policy allowed democratic reading.

With the shift of concept of PUCRS, Dentistry has become a part of the School of Health Sciences. With that, the role of each faculty's journal has been redesigned to fit into a broader spectrum. Therefore, it is heartbreaking for me that I announce the closure of activities of Revista Odonto Ciência. On the other hand, it may be a step further towards the launch of a journal connected with all areas of health sciences.

We would like to thank the hard and competent work of our previous editors, Telmo Bandeira Berthold and Rosemary Sadami Arai Shinkai, together with everyone who helped to enhance the quality of our journal. My very special thanks to the current editorial board, composed of Maria Martha Campos, Eduardo Gonçalves Mota, Altair Antoninha Del Bel Cury, Saul Martins Paiva and Daiana Elisabeth Böttcher. Daiana Böttcher, particularly, has become the hands, the brain and the heart of this journal in the last 3 years, and I thank her from the bottom of my heart.

Dear readers, the journal will be kept available online so the memory and content of the publications is not lost. I dedicate to you this last editorial, who trusted that our work was worth visiting and reading, and which is the ultimate reason for our existence. And now, for our farewell. Thank you very much! 